\title{
Synthesis and Optical Properties of B-Mg co-Doped ZnO Nanoparticles
}

\author{
Yuechan $\mathrm{Li}^{1,2}$, Yongli $\mathrm{Li}^{1,2}$ and An Xie ${ }^{1,2, *(D)}$ \\ 1 School of Materials Science and Engineering, Xiamen University of Technology, Xiamen 361024, China; \\ liyuechan@xmut.edu.cn (Y.L.); lyl606614@163.com (Y.L.) \\ 2 Key Laboratory of Functional Materials and Applications of Fujian Province, Xiamen 361024, China \\ * Correspondence: anxie@xmut.edu.cn
}

check for

updates

Citation: Li, Y.; Li, Y.; Xie, A.

Synthesis and Optical Properties of B-Mg co-Doped ZnO Nanoparticles. Coatings 2021, 11, 882. https:// doi.org/10.3390/coatings11080882

Academic Editor:

Alessandro Pezzella

Received: 5 July 2021

Accepted: 21 July 2021

Published: 23 July 2021

Publisher's Note: MDPI stays neutral with regard to jurisdictional claims in published maps and institutional affiliations.

Copyright: (c) 2021 by the authors. Licensee MDPI, Basel, Switzerland. This article is an open access article distributed under the terms and conditions of the Creative Commons Attribution (CC BY) license (https:/ / creativecommons.org/licenses/by/ $4.0 /)$.

\begin{abstract}
Doping impurity into $\mathrm{ZnO}$ is an effective and powerful technique to tailor structures and enhance its optical properties. In this work, $\mathrm{Zn}_{1-x} \mathrm{Mg}_{x} \mathrm{O}$ and $\mathrm{Zn}_{1-x-y} \mathrm{Mg}_{x} \mathrm{~B}_{y} \mathrm{O}$ nanoparticles $(x=0$, $0.1,0.2,0.3,0.4 ; y=0,0.02,0.04)$ were synthesized via one-pot method. It shows that the $\mathrm{Mg}$ and $\mathrm{B}$ dopants has great influence on crystallinity and surface morphology of $\mathrm{ZnO}$ nanoparticles, without changing the wurtzite structure of $\mathrm{ZnO}$. The band structure study indicates that the competition of Conductive Band (CB) shift, Burstein-Moss (B-M) shift and Shrinkage effect will cause the band gap energy change in $\mathrm{ZnO}$.
\end{abstract}

Keywords: one-pot method; B-Mg co-doped $\mathrm{ZnO}$; crystal structure; optical band gap

\section{Introduction}

As one of the third-generation wide band gap semiconductor materials, zinc oxide $(\mathrm{ZnO})$ has attracted great attention in the field of optoelectronic functional materials due to its excellent physical and chemical properties, such as large exciton binding energy $(60 \mathrm{meV})$, wide direct band gap energy $(3.37 \mathrm{eV})$, low cost, and facile preparation [1-4]. In recent years, researchers have discovered that $\mathrm{ZnO}$ nanoparticles (NPs) have unique and superior structural, optical, electronic, and chemical properties compared to bulk $\mathrm{ZnO}$ materials [5,6]. Therefore, various methods for preparing ZnO NPs have been developed, such as co-precipitation, hydrothermal, combustion, spray pyrolysis, sol-gel, and hightemperature pyrolysis [7-11].

Doping impurity elements into the target lattice is an effective and powerful technique that can change the electronic structure and enhance electrical and optical properties [12]. Various elements (for example, $\mathrm{Al}, \mathrm{Ga}, \mathrm{Mg}, \mathrm{Mn}$ ) [13-16] have been used as donors to improve the optical, physical, and chemical properties of $\mathrm{ZnO}$. Among them, $\mathrm{Mg}$-doped $\mathrm{ZnO}$ NPs have attracted great attention; because the ionic radius between $\mathrm{Mg}^{2+}$ and $\mathrm{Zn}^{2+}$ is equivalent, doping $\mathrm{Mg}$ element will not cause huge lattice changes. Moreover, because of the large band gap of $\mathrm{MgO}, \mathrm{Mg}$ doping can broaden the optical band gap of $\mathrm{ZnO}[17,18]$. Jongchul Seo [19] synthesized $\mathrm{Mg}$-doped $\mathrm{ZnO}\left(\mathrm{Zn}_{1-x} \mathrm{Mg}_{x} \mathrm{O}\right.$, where $x=0.000-0.010 \mathrm{M}$ ) nanoparticles via a co-precipitation method and showed an increase in the optical band gap from 3.32 to $3.51 \mathrm{eV}$ with respect to the increase in the concentration of $\mathrm{Mg}$ doping. Riffat Sagheer [5] synthesized $\mathrm{Zn}_{1-x} \mathrm{Mg}_{x} \mathrm{O}$ nanoparticles $(x=0-0.1$, $\Delta x=0.02)$ via a co-precipitation method; the $E_{g}$ of $\mathrm{Mg}$-doped $\mathrm{ZnO}$ nanoparticles $(3.080 \mathrm{eV})$ is greater than that of undoped $\mathrm{ZnO}$ nanoparticles $(3.038 \mathrm{eV})$. XRD results confirmed that the synthesized nanoparticles are polycrystalline, which have a typical hexagonal wurtzite structure, and there are no other impurities or dopant phases in the $\mathrm{ZnO}$ crystal lattice. Charis Caroline [20] synthesized pure $\mathrm{ZnO}$ and $\mathrm{Mg}$ doped $\mathrm{ZnO}\left(\mathrm{Zn}_{1-x} \mathrm{Mg}_{x} \mathrm{O}\right.$; $x=0,0.2,0.4)$ by sol-gel method. The results show that the $E_{g}$ increases from 3.16 to $3.24 \mathrm{eV}$ with the $\mathrm{Mg}$ concentration from 0 to 0.4 . 
In addition, the group III elements are usually doped to increase the electrical properties of $\mathrm{ZnO}$ by increasing the carrier concentration [21]. $\mathrm{Al}$ is considered to be the best doping element to enhance optical and electrical properties [22]. B element is also used to investigate the transparent and electrically conductive of $\mathrm{ZnO}$ and found that the transmittance of B-doped $\mathrm{ZnO}$ thin films were obviously improved [23,24], but the optical band gap was decreased [21].

Although lots of research was carried out on the elements doping in $\mathrm{ZnO}$, the effect of $\mathrm{B}-\mathrm{Mg}$ co-doped was rarely seen. Therefore, in this work, pure $\mathrm{ZnO}, \mathrm{Mg}$-doped $\mathrm{ZnO}$, and B-Mg co-doped ZnO NPs were synthesized by simple one-pot method. The effect of $\mathrm{Mg}$ and $\mathrm{B}$ doping on crystal structure, morphology, and the band structure of $\mathrm{ZnO}$ will be investigated.

\section{Materials and Methods}

\subsection{Synthesis of Nanoparticles}

For the present research work, $\mathrm{Zn}_{1-x} \mathrm{Mg}_{x} \mathrm{O}$ and $\mathrm{Zn}_{1-x-y} \mathrm{Mg}_{x} \mathrm{~B}_{y} \mathrm{O}$ nanoparticles $(x=0,0.1,0.2,0.3,0.4 ; y=0,0.02,0.04)$ were synthesized via one-pot method. Here Zinc acetylacetonate $\left(\mathrm{Zn}(\mathrm{acac})_{2}\right)$, Magnesium acetylacetonate $\left(\mathrm{Mg}(\mathrm{acac})_{2}\right)$, Boric acid $\left(\mathrm{H}_{3} \mathrm{BO}_{3}\right)$ were used as the $\mathrm{Zn}$ source, $\mathrm{Mg}$ source and B source, respectively. All the chemical ingredients were weighted in stoichiometric proportions for getting $10 \mathrm{mmol}$ of final product. Then, a mixture of $\mathrm{Zn}(\mathrm{acac})_{2}, \mathrm{Mg}(\mathrm{acac})_{2}, \mathrm{H}_{3} \mathrm{BO}_{3}$, oleic acid (OA, $\left.0.9 \mathrm{~g}\right)$, oleylamine (OAm, $2.50 \mathrm{~g})$, and octadecene (ODE, $13.2 \mathrm{~g}$ ) with specific composition was degassed at $120^{\circ} \mathrm{C}$ for $30 \mathrm{~min}$ and heated to $280^{\circ} \mathrm{C}$ in a closed beaker. The hot mixture was cooled to room temperature naturally in the air, and then, $30 \mathrm{~mL}$ of ethanol was added to precipitate the nanoparticles, the mixture solution was centrifuged at $5000 \mathrm{r} / \mathrm{min}$ for $5 \mathrm{~min}$ to get white precipitates. The precipitates were redispersed in $10 \mathrm{~mL}$ of $\mathrm{n}$-hexane and washed with ethanol for three times. Finally, the precipitates were dried in hot air oven at $100{ }^{\circ} \mathrm{C}$ for $10 \mathrm{~h}$. The dried precipitates were crushed to obtain desired nanoparticles.

\subsection{Characterization of Nanoparticles}

The crystal structure of all samples were characterized by X-ray diffraction with CuKa radiation (XRD, Rigaku, Tokyo, Japan). Analysis of surface features of all nanoparticles were carried out by using Sigma 500 Scanning electron microscope (SEM, Carl Zeiss AG, Jena, Germany) and Talos-F200s Transmission electron microscope(TEM, FEI, Waltham, MA, USA). Optical properties of the nanoparticles were explored by employing by a Scan UV spectrophotometer (UV-2700, Shimadzu, Tokyo, Japan). The UV diffuse reflectance spectroscopy were recorded at room temperature ranging from 200 to $800 \mathrm{~nm}$.

\section{Results}

\subsection{XRD Analysis}

To investigate the structural aspects of the $\mathrm{ZnO}, \mathrm{Mg}$ doped $\mathrm{ZnO}$ and $\mathrm{B}-\mathrm{Mg}$ doped $\mathrm{ZnO}$ nanoparticles, XRD patterns of all samples were listed and analyzed. The XRD patterns of $\mathrm{Zn}_{1-x} \mathrm{Mg}_{x} \mathrm{O}$ nanoparticles with different doping concentrations $(x=0,0.1,0.2,0.3,0.4)$ synthesized by the one-pot method are shown in Figure 1a,b. It can be seen from the patterns that the synthesized nanoparticles have sharp diffraction peaks, which indicates that the prepared nanoparticles have good crystallinity. The characteristic diffraction peaks indicate that the synthesized nanocrystals are $\mathrm{ZnO}$ with a wurtzite hexagonal structure (PDF\# 80-0074). Moreover, no characteristic peak corresponding to the " $\mathrm{Mg}^{\prime}$ " element or its compound was detected, which indicates that " $\mathrm{Mg}$ " is a dopant, and no additional $\mathrm{Mg}$ related extrinsic phase exists in the $\mathrm{ZnO}$ matrix. For the wurtzite phase, calculate the lattice constants " $a$ " and " $c$ " of (100) and (002), respectively, as follows [25]. 

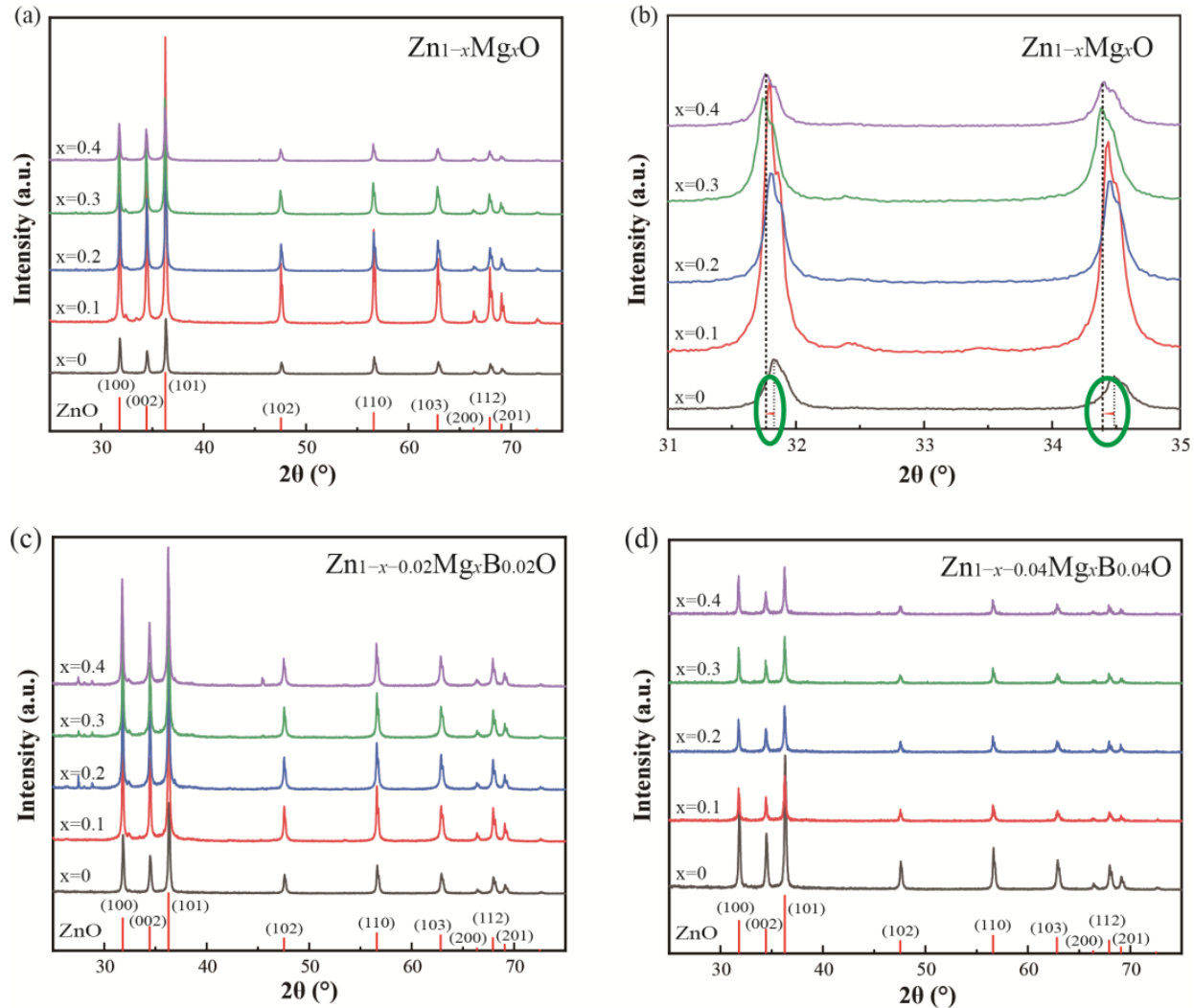

Figure 1. XRD pattern of $\mathrm{Zn}_{1-x-y} \mathrm{Mg}_{x} \mathrm{~B}_{y} \mathrm{O}$. (a) $\mathrm{Zn}_{1-x} \mathrm{Mg}_{x} \mathrm{O}$; (b) enlarged XRD pattern of (100) and (002) plane of $\mathrm{Zn}_{1-x} \mathrm{Mg}_{x} \mathrm{O}$ in (a); (c) $\mathrm{Zn}_{1-x-0.02} \mathrm{Mg}_{x} \mathrm{~B}_{0.02} \mathrm{O}$; (d) $\mathrm{Zn}_{1-x-0.04} \mathrm{Mg}_{x} \mathrm{~B}_{0.04} \mathrm{O}$.

$$
\begin{gathered}
a=\frac{\lambda}{\sqrt{3} \sin \theta_{(100)}}, \\
c=\frac{\lambda}{\sin \theta_{(002)}},
\end{gathered}
$$

where $\lambda$ is the wavelength of the incident $X$-ray $(\lambda=1.5406 \AA)$, and $\theta$ is the Bragg angle. The influence of " $\mathrm{Mg}^{\prime}$ " atoms was investigated through the changes of peak positions of (100) and (002) planes, as in Figure 1b. Both peaks move to the lower $2 \theta$ value, as shown in the two circles in Figure $1 \mathrm{~b}$, indicating that the " $\mathrm{Mg}^{\prime}$ " atoms occupy the substitution lattice sites and interstitial sites [5]. However, the aspect ratio " $c / a$ " listed in Table 1 is almost constant, which indicates that the dopant atoms are successfully combined with the $\mathrm{ZnO}$ host lattice without changing the crystal structure of the nanoparticles. In addition, according to Vegard's law, a slight increase in the lattice parameters (" $a$ " and " $c$ ") of the $\mathrm{ZnO}$ lattice is noticed due to the high $\mathrm{Mg}$ doping concentration. 
Table 1. Calculated parameters for nanoparticles.

\begin{tabular}{|c|c|c|c|c|c|c|c|c|}
\hline Compounds & $\begin{array}{c}\text { Dopant } \\
x\end{array}$ & \multicolumn{2}{|c|}{ Lattice Parameters } & $a / c$ & $\begin{array}{l}\text { Volume of } \\
\text { Unit Cell } V\end{array}$ & $\begin{array}{c}\text { Crystallite Size } \\
D(\mathrm{~nm})\end{array}$ & $\begin{array}{l}\text { Dislocation } \\
\text { Density }\end{array}$ & Strain \\
\hline $\mathrm{ZnO}$ & & 3.244 & 5.198 & 1.603 & 47.366 & 38.885 & 6.614 & 8.914 \\
\hline \multirow{4}{*}{$\mathrm{Zn}_{1-x} \mathrm{Mg}_{x} \mathrm{O}$} & 0.1 & 3.247 & 5.204 & 1.603 & 47.510 & 46.441 & 4.637 & 7.464 \\
\hline & 0.2 & 3.246 & 5.201 & 1.602 & 47.473 & 43.315 & 5.330 & 8.003 \\
\hline & 0.3 & 3.252 & 5.212 & 1.603 & 47.750 & 42.863 & 5.443 & 8.087 \\
\hline & 0.4 & 3.251 & 5.209 & 1.603 & 47.662 & 39.803 & 6.312 & 8.709 \\
\hline \multirow{4}{*}{$\mathrm{Zn}_{1-x-0.02} \mathrm{Mg}_{x} \mathrm{~B}_{0.02} \mathrm{O}$} & 0.1 & 3.245 & 5.200 & 1.601 & 47.497 & 43.090 & 5.386 & 8.044 \\
\hline & 0.2 & 3.250 & 5.203 & 1.601 & 47.578 & 40.190 & 6.191 & 8.625 \\
\hline & 0.3 & 3.248 & 5.201 & 1.602 & 47.510 & 39.247 & 6.492 & 8.832 \\
\hline & 0.4 & 3.251 & 5.207 & 1.602 & 47.650 & 39.061 & 6.554 & 8.874 \\
\hline \multirow{4}{*}{$\mathrm{Zn}_{1-x-0.04} \mathrm{Mg}_{x} \mathrm{~B}_{0.04} \mathrm{O}$} & 0.1 & 3.250 & 5.204 & 1.601 & 47.596 & 39.999 & 6.250 & 8.666 \\
\hline & 0.2 & 3.248 & 5.204 & 1.602 & 47.542 & 41.795 & 5.725 & 8.294 \\
\hline & 0.3 & 3.250 & 5.204 & 1.601 & 47.596 & 39.248 & 6.492 & 8.832 \\
\hline & 0.4 & 3.249 & 5.206 & 1.602 & 47.583 & 40.579 & 6.073 & 8.542 \\
\hline
\end{tabular}

Besides, the average crystallite size $D$ was calculated from XRD peak of (101) by using the Debye-Scherrer equation, the dislocation density $\delta$ is defined as the length of dislocation lines per unit volume of the crystal, which is determined from the crystallite size $D$. We can also calculate the strain $\varepsilon$ caused by the crystal defects and distortion [25].

$$
\begin{gathered}
D=\frac{\mathrm{K} \lambda}{\beta_{\mathrm{hkl}} \cos \theta}, \\
\delta=\frac{1}{D^{2}}, \\
\varepsilon=\frac{\beta_{\mathrm{hkl}} \cos \theta}{4},
\end{gathered}
$$

where $\beta_{\mathrm{hkl}}$ is the integral half width, $\mathrm{K}$ is a constant equal to 0.9 . The calculated data are shown in Table 1. The crystal size of pure $\mathrm{ZnO}$ synthesized by one-pot method is only $38.9 \mathrm{~nm}$, and it can be observed that the crystallite size increases while " $\mathrm{Mg}^{\text {" atoms was }}$ doped, as shown in Table 1. Internal strain is generated in the parent $\mathrm{ZnO}$ system due to the difference between the ionic radii of $\mathrm{Zn}(0.057 \mathrm{~nm})$ and $\mathrm{Mg}(0.060 \mathrm{~nm})$. When the amount of doped $\mathrm{Mg}$ is small $(x=0.1)$, the doping atoms accelerate the diffusion rate in the $\mathrm{Mg}$-doped $\mathrm{ZnO}$ nanoparticles due to the small volume of $\mathrm{Mg}^{2+}$ ions, resulting in a larger crystal size. The reason may be due to the low Pauling electro-negativity (1.31) and the high reactivity of $\mathrm{Mg}$ [5]. However, as presented in Table 1, the crystal size D of the sample decreases as the doping concentration increases $(x=0.2,0.3,0.4)$ due to the influence of lattice strain and dislocation density [26].

Figure 1c, d shows the XRD images of B-Mg co-doped $\mathrm{ZnO}$ nanoparticles with different $B$ doping concentrations $(y=0.02,0.04)$. Similar to Figure $1 \mathrm{a}$, the addition of $\mathrm{B}$ element would not cause other additional peaks, indicating that B-Mg co-doping did not change the wurtzite structure of $\mathrm{ZnO}$. However, the peak intensity decreases as the concentration of $B$ increases, which indicates that the crystalline quality of the product is poor.

The differences between the crystallite size $\mathrm{D}$ of $\mathrm{Zn}_{1-x} \mathrm{Mg}_{x} \mathrm{O}$ and the one of $\mathrm{B}$ codoped $\mathrm{Zn}_{1-x} \mathrm{Mg}_{x} \mathrm{O}$ are presented in Figure 2a, to investigate the influence of $\mathrm{B}$ element. We have a medium D of $43.3 \mathrm{~nm}$ for $\mathrm{Zn}_{1-x} \mathrm{Mg}_{x} \mathrm{O}$ sample, while in presence of $\mathrm{B}$ medium, $\mathrm{D}$ is 40.3 and $40.5 \mathrm{~nm}$. It seems that the $\mathrm{Mg}$ concentration is less effective on the variation of $\mathrm{D}$ when samples are co-doped with B. The reason may be that the incorporation of B element increases the lattice strain and dislocation density of zinc oxide nanoparticles [26], as shown in Table 1 and Figure 2b,c. 

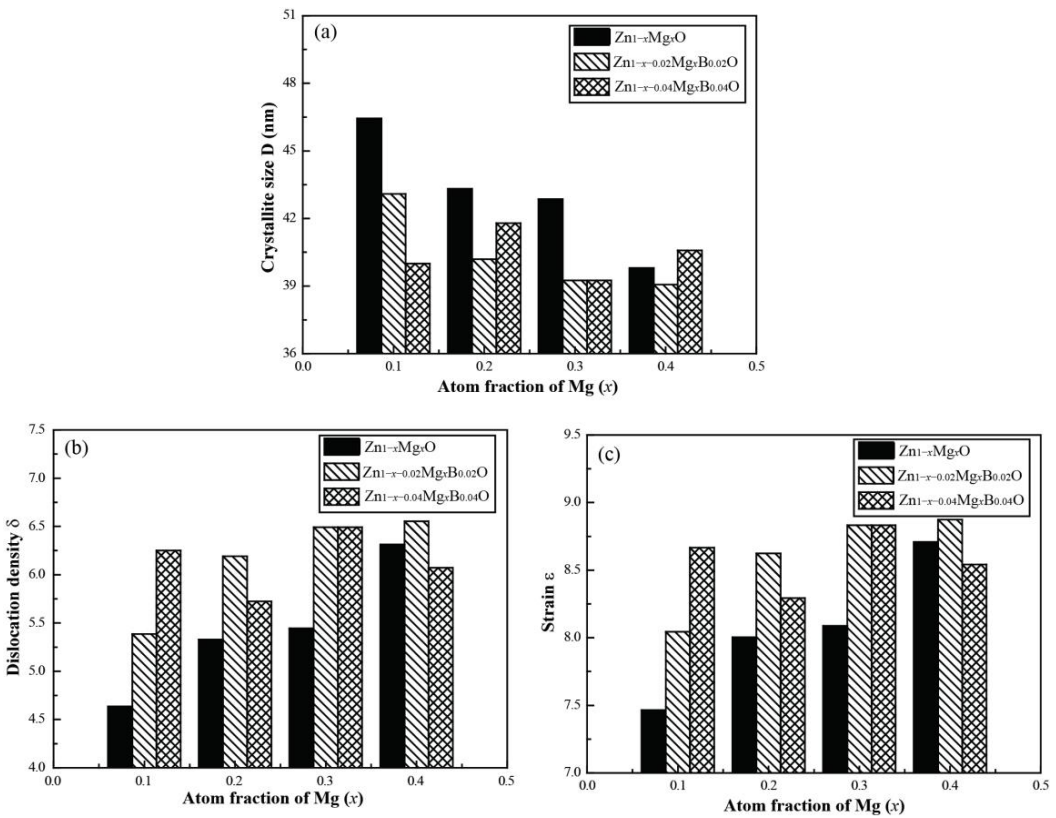

Figure 2. Comparison of calculated parameters of $\mathrm{Zn}_{1-x-y} \mathrm{Mg}_{x} \mathrm{~B}_{y} \mathrm{O}$ with different fraction of $\mathrm{Mg}$. (a) crystallite size D; (b) dislocation density; (c) strain.

\subsection{SEM and TEM Analysis}

Using scanning electron microscope to study the effect of $\mathrm{B}$ and $\mathrm{Mg}$ doping on the surface morphology of $\mathrm{ZnO}$ nanoparticles, as presented in Figure 3. It can be observed that the pure $\mathrm{ZnO}$ synthesized by one-pot method has triangular and spherical grains and are seriously aggregated. When $\mathrm{Mg}$ doped in $\mathrm{ZnO}$, as presented in Figure $3 \mathrm{~b}-\mathrm{d}$, discal and hexagonal shapes appear, which means that the orientation of the sample is mostly perpendicular to the growth direction along the c-axis [27]. Besides, twinned crystal structures with a central vacant space in each twined building block have selfassembled. This phenomenon indicates that $\mathrm{Mg}$ element promotes the crystallization of $\mathrm{ZnO}$. Comparing Figure $3 \mathrm{~d}-\mathrm{f}$, it can be seen that with the addition of $\mathrm{B}$ element, the twin hexagonal crystal structure gradually disappears, and only a spherical structure exists in the $\mathrm{Zn}_{0.68} \mathrm{Mg}_{0.3} \mathrm{~B}_{0.02} \mathrm{O}$ sample in Figure $3 \mathrm{f}$. The $\mathrm{B}$ element reduces the crystallinity of $\mathrm{ZnO}$, which is in agreement with the result of XRD.
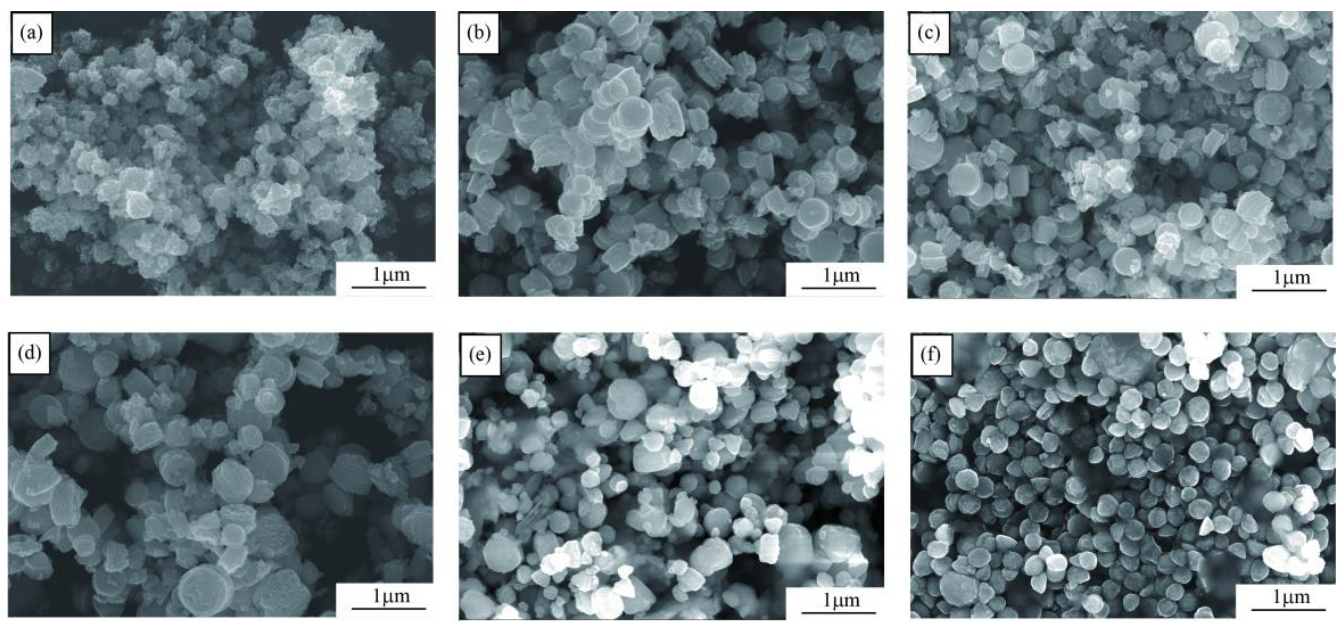

Figure 3. SEM images of pure and doped $\mathrm{ZnO}$ nanoparticles. (a) Pure $\mathrm{ZnO}$; (b) $\mathrm{Zn}_{0.9} \mathrm{Mg}_{0.1} \mathrm{O}$; (c) $\mathrm{Zn}_{0.6} \mathrm{Mg}_{0.4} \mathrm{O}$; (d) $\mathrm{Zn}_{0.7} \mathrm{Mg}_{0.3} \mathrm{O}$; (e) $\mathrm{Zn}_{0.68} \mathrm{Mg}_{0.3} \mathrm{~B}_{0.02} \mathrm{O}$; (f) $\mathrm{Zn}_{0.66} \mathrm{Mg}_{0.3} \mathrm{~B}_{0.04} \mathrm{O}$. 
The typical transmission electronic microscopy (TEM) images of pure $\mathrm{ZnO}, \mathrm{Zn}_{0.7} \mathrm{Mg}_{0.3} \mathrm{O}$, $\mathrm{Zn}_{0.68} \mathrm{Mg}_{0.3} \mathrm{~B}_{0.02} \mathrm{O}$, and $\mathrm{Zn}_{0.66} \mathrm{Mg}_{0.3} \mathrm{~B}_{0.04} \mathrm{O}$ nanoparticles are presented in Figure 4. Pure $\mathrm{ZnO}$ nanoparticles with an average particle size of $20-50 \mathrm{~nm}$ are agglomerated. The wellresolved interfringe distance of $2.89 \AA$ corresponds to the (100) lattice planes of $\mathrm{ZnO}$. In the $\mathrm{Zn}_{0.7} \mathrm{Mg}_{0.3} \mathrm{O}$ sample, discal-shaped particles showing good crystallinity are observed, which is consistent with the SEM results. After doping B ions, only spherical structures are present in Figure $4 c, d$. In addition, the lattice resolved images in Figure $4 b-d$ all show that the lattice spacing is $2.85 \AA$, which can correspond to the (100) plane of $\mathrm{ZnO}$, confirming that B-Mg co-doping did not change the structure of wurtzite zinc oxide.

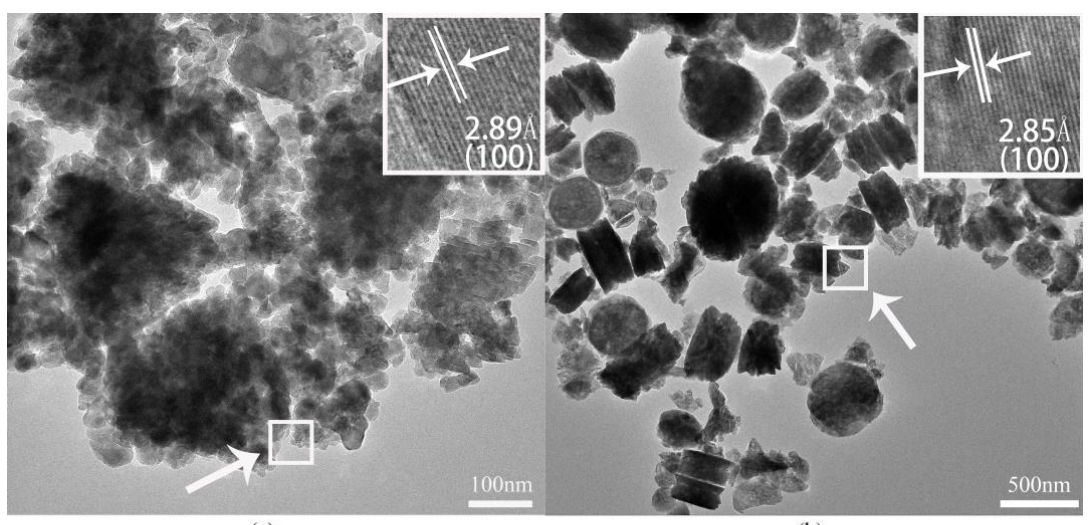

(a)

(b)

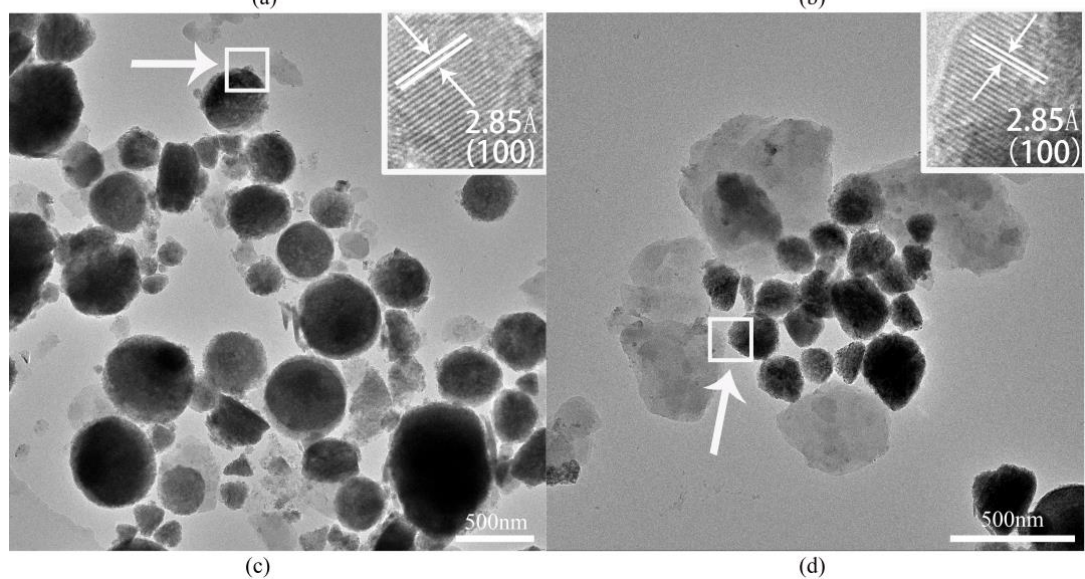

Figure 4. Typical transmission electronic microscopy (TEM) images of (a) pure $\mathrm{ZnO}$, (b) $\mathrm{Zn}_{0.7} \mathrm{Mg}_{0.3} \mathrm{O}$, (c) $\mathrm{Zn}_{0.68} \mathrm{Mg}_{0.3} \mathrm{~B}_{0.02} \mathrm{O}$, and (d) $\mathrm{Zn}_{0.66} \mathrm{Mg}_{0.3} \mathrm{~B}_{0.04} \mathrm{O}$ nanoparticles.

\subsection{UV-VIS Analysis}

Ultraviolet-visible spectroscopy was used to study and analyze the optical properties of pure and B-Mg co-doped $\mathrm{ZnO}$ nanoparticles. Figure 5 presents the UV diffuse reflectance spectra of pure and $\mathrm{Mg}$-doped $\mathrm{ZnO}$ nanoparticles with different $\mathrm{Mg}$ concentrations. It can be observed that there is a blue shift of the reflection peak between 370 and $400 \mathrm{~nm}$. This is a phenomenon in which the band gap of a semiconductor increases, that is, the absorption is pushed to higher energy due to an increase in the population in the conduction band. On further observation, as shown in the enlarged image in Figure 5a, compared with pure $\mathrm{ZnO}, \mathrm{Mg}$-doped $\mathrm{ZnO}$ nanoparticles have higher reflectance, which is due to the increase in $E_{g}$. 


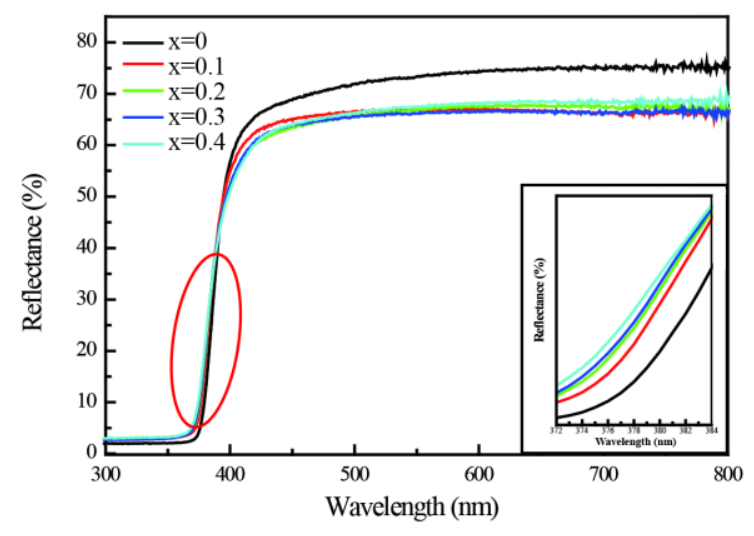

(a)

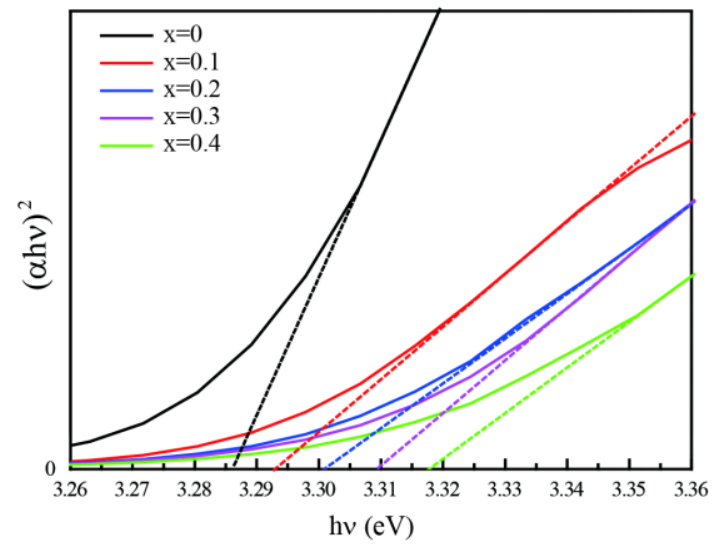

(b)

Figure 5. (a) UV reflectance spectra of $\mathrm{Zn}_{1-x} \mathrm{Mg}_{x} \mathrm{O}$ nanoparticles; the inset is the enlarged figure in the red circle; (b) Tauc plots for determination of optical band gap energy of $\mathrm{Zn}_{1-x} \mathrm{Mg}_{x} \mathrm{O}$ nanoparticles.

The optical bandgap energy was calculated by the Kubelka-Munk equation [28], as follows.

$$
F(R)=\frac{(1-R)^{2}}{2 R}
$$

where $R$ is the reflectance. $F(R)$ is the absorption coefficient $(\alpha)$ in Tauc equation [28]:

$$
(\alpha h v)^{2}=A\left(h v-E_{g}\right),
$$

We estimate the $E_{g}$ by extrapolating the linear plot of the Tauc equation, as presented in Figure $5 \mathrm{~b}$. It can be observed that the $E_{g}$ values increased from $3.286 \mathrm{eV}$ to $3.318 \mathrm{eV}$ for undoped $\mathrm{ZnO}$ and $\mathrm{Zn}_{0.6} \mathrm{Mg}_{0.4} \mathrm{O}$ nanoparticles. It is because of the conduction band shift ( $\mathrm{CB}$ shift) owing to the wider $E_{g}$ of $\mathrm{MgO}(7.7 \mathrm{eV})$, as presented in Figure $6 \mathrm{~b}$. In addition, the $E_{g}$ of $\mathrm{Zn}_{1-x} \mathrm{Mg}_{x} \mathrm{O}$ nanoparticles increase gradually with the increase of the Mg dopants. The reason may be due to the Burstein-Moss shift (B-M shift) caused by more electrons generated by substituting $\mathrm{Mg}^{2+}$ ions in $\mathrm{ZnO}$. The schematic showing effect of $\mathrm{CB}$ shift and B-M shift is presented in Figure 6c.
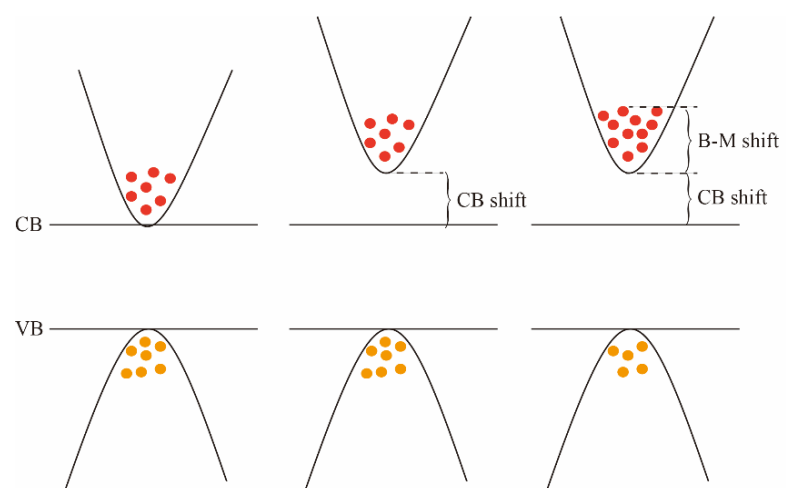

(a)
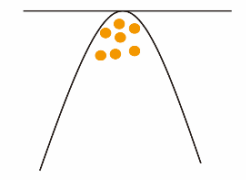

(b)

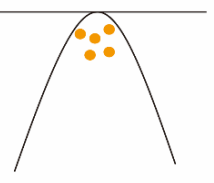

(c)
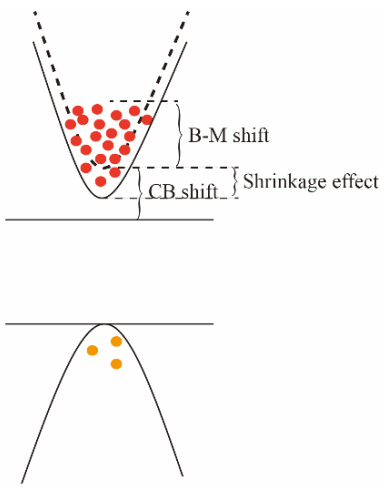

(d)

Figure 6. Schematic showing effect of doping on $\mathrm{ZnO}$ band structure. (a) Band structure of pure $\mathrm{ZnO}$; (b) $\mathrm{CB}$ shift of band structure during doping; (c) both $\mathrm{CB}$ shift and B-M shift of band structure when the carrier concentration $C<C_{\text {Mott }}$ (d) CB shift, B-M shift, and shrinkage effect of band structure when the carrier concentration $C>C_{\text {Mott }}$.

The influence of the B element on the $E_{g}$ is also studied. The calculated $E_{g}$ of pure and doped $\mathrm{ZnO}$ nanoparticles are presented in Figure 7. Different from $\mathrm{Mg}$-doped $\mathrm{ZnO}$ nanoparticles, the $E_{g}$ of $\mathrm{B}-\mathrm{Mg}$ co-doped $\mathrm{ZnO}$ increases first and then decreases while the doping amount of Mg element gradually increases. A small number of carriers induced by 
doping will cause Burstein-Moss shift, broadening $E_{g}$, as shown in Figure 6c. However, when the concentration of carriers is higher than the critical concentration of Mott transition $\left(C_{M o t t}\right)$, Urbach tail will cause the shrinkage of energy gap [29], which is shown in Figure $6 \mathrm{~d}$. It is known that the replacement of $\mathrm{B}^{3+}$ atom with host $\mathrm{Zn}^{2+}$ atom generates a large amount of carrier, and excessive carrier concentration results in the decreasing of $E_{g}$ (Shrinkage effect).

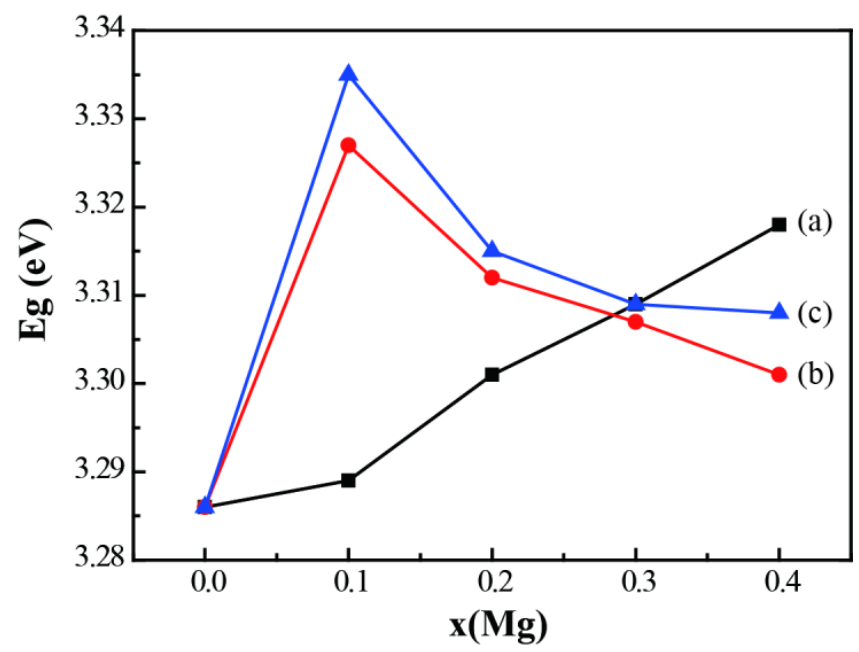

Figure 7. Band gap energy $E_{g}$ of pure and doped $\mathrm{ZnO}$ nanoparticles. (a) $\mathrm{Zn}_{1-x} \mathrm{Mg}_{x} \mathrm{O}$; (b) $\mathrm{Zn}_{1-0.02-x} \mathrm{Mg}_{x} \mathrm{~B}_{0.02} \mathrm{O}$; (c) $\mathrm{Zn}_{1-0.04-x} \mathrm{Mg}_{x} \mathrm{~B}_{0.04} \mathrm{O}$.

\section{Conclusions}

The pure and doped $\mathrm{ZnO}$ nanoparticles were successfully synthesized by a simple one-pot method. XRD results show that both $\mathrm{Mg}$ and $\mathrm{B}$ are incorporated into the $\mathrm{ZnO}$ lattice without changing the original wurtzite structure of $\mathrm{ZnO}$. By introducing $\mathrm{Mg}$ element into $\mathrm{ZnO}$ nanoparticles, the lattice parameter is increased. However, the B element increases the lattice strain and dislocation density, thereby decreasing the crystallite size. Combined with the analysis of the microstructure, it can be seen that $\mathrm{Mg}$ ions promote the crystallization of $\mathrm{ZnO}$, while B ions make the crystallinity worse. The influence of doping $\mathrm{Mg}$ and $\mathrm{B}$ on the band structure is also investigated. The results show that the $E_{g}$ of $\mathrm{ZnO}$ nanoparticles increase with doping $\mathrm{Mg}$, while that of $\mathrm{B}-\mathrm{Mg}$ co-doped $\mathrm{ZnO}$ increases first and then decreases due to the competition of CB shift, Burstein-Moss shift and Shrinkage effect.

Author Contributions: Y.L. (Yongli Li): methodology, formal analysis, and data curation. Y.L. (Yuechan Li): conceptualization, investigation, writing-original draft preparation. A.X.: writingreview and editing, funding acquisition. All authors have read and agreed to the published version of the manuscript.

Funding: The research work was supported by National Natural Science Foundation of China Joint Fund for Cross-strait Scientific and Technological Cooperation (No. U2005212), Key Project of Natural Science Foundation of Fujian Province (No. 2020J02049), Major Project of Science and technology of Xiamen City (Nos. 3502ZCQ20201001, 3502Z20201003), the Natural Science Foundation of Fujian Province (No. 2019J01873), open fund of Fujian Provincial Key Laboratory of Functional Materials and Applications, Xiamen University of Technology (No. fma2020009), and Pandengketi of Xiamen University of Technology (No. XPDKQ20002).

Institutional Review Board Statement: Not applicable.

Informed Consent Statement: Not applicable.

Data Availability Statement: Data sharing not applicable.

Conflicts of Interest: The authors declare no conflict of interest. 


\section{References}

1. Yogamalar, N.R.; Bose, A.C. Absorption-emission of hydrothermally grown Al: ZnO nanostructures. J. Alloys Compd. 2011, 509, 8493-8500. [CrossRef]

2. Singh, S.; Thiyagarajan, P.; Kant, K.M.; Anita, D.; Thirupathiah, S.; Rama, N.; Tiwari, B.; Kottaisamy, M.; Rao, M.S.R. Structure, microstructure and physical properties of $\mathrm{ZnO}$ based materials in various forms: Bulk, thin film and nano. Phys. D Appl. Phys. 2007, 40, 6312-6327. [CrossRef]

3. Yi, G.; Wang, C.; Park, W. ZnO nanorods: Synthesis, characterization and applications. Semicond. Sci. Technol. 2005, 20, S22-S34. [CrossRef]

4. Chaudhary, P.; Singh, P.; Kumar, V. Synthesis and characterization of pure $\mathrm{ZnO}$ and La-doped $\mathrm{ZnO}\left(\mathrm{Zn}_{0.98} \mathrm{La}_{0.02} \mathrm{O}\right)$ films via novel sol-gel screen-printing method. Optik 2018, 158, 376-381. [CrossRef]

5. Sagheer, R.; Khalil, M.; Abbas, V.; Kayani, Z.N.; Tariq, U. Effect of Mg doping on structural, morphological, optical and thermal properties of ZnO nanoparticles. Optik 2020, 200, 163428. [CrossRef]

6. Golic, D.L.; Brankovic, G.; Nesic, M.P.; Vojisavljevic, K.; Recnikn, A.; Daneu, N.; Bernik, S.; Scepanovic, M.; Poleti, D.; Brankovic, Z. Structural charecterization of self-assembled $\mathrm{ZnO}$ nanoparticles obtained by the sol-gel method from $\mathrm{Zn}\left(\mathrm{CH} \mathrm{COO}_{2} 2 \mathrm{H}_{2} \mathrm{O}\right.$. Nanotechnology 2011, 22, 395603. [CrossRef] [PubMed]

7. Raoufi, D. Synthesis and microstructural properties of ZnO nanoparticles prepared by precipitation method. Renew. Energy 2013, 50, 932-937. [CrossRef]

8. Sitthichai, S.; Phuruangrat, A.; Thongtem, T.; Thongtem, S. Influence of Mg dopant on photocatalytic properties of Mg-doped ZnO nanoparticles prepared by sol-gel method. J. Ceram. Soc. Jpn. 2017, 125, 122-124. [CrossRef]

9. Lakshmipriya, V.; Radha, K.P. Synthesis, structural, vibrational, thermal studies of Mg doped ZnO nanoparticles using chemical precipitation method. Int. J. Multidiscip. Educ. Res. 2016, 1, 39-42.

10. Aneesh, P.M.; Vanaja, K.A.; Jayaraj, M.K. Synthesis of ZnO nanoparticles by hydrothermal method. Proc. SPIE 2007, 6639, 66390J.

11. Bai, D.S.; Kumar, V.R.; Suvarna, R.P. Synthesis and characterization of zinc oxide nanoparticles by solution combustion method: DC conductivity studies. Indian J. Adv. Chem. Sci. 2017, 5, 137-141.

12. Liu, S.Y.; Zhu, L.S.; Cao, W.S.; Li, P.D.; Zhan, Z.L.; Chen, Z.H.; Yuan, X.; Wang, J. Defect-related optical properties of Mg-doped $\mathrm{ZnO}$ nanoparticles synthesized via low temperature hydrothermal method. J. Alloys Compd. 2021, 858, 157654. [CrossRef]

13. Kurtaran, S. Al doped $\mathrm{ZnO}$ thin films obtained by spray pyrohysis technique: Influence of different annealing time. Opt. Mater. 2021, 114, 110908. [CrossRef]

14. Park, G.C.; Hwang, S.M.; Choi, J.H.; Kwon, Y.H.; Cho, H.K.; Kim, S.W.; Lim, J.H.; Joo, J. Effects of In or Ga doping on the growth behavior and optical properties of ZnO nanorods fabricated by hydrothermal process. Phys. Status Solidi Appl. Mater. Sci. 2013, 210, 1552-1556. [CrossRef]

15. Srinet, G.; Sharma, S.; Kumar, M.; Anshul, A. Structural and optical properties of Mg modified ZnO nanoparticles: An X-ray peak broadening analysis. Phys. E Low-Dimens. Syst. Nanostruct. 2021, 125, 114381. [CrossRef]

16. Putri, N.A.; Fauzia, V.; Iwan, S.; Roza, L.; Umar, A.A.; Budi, S. Mn-doping-induced photocatalytic activity enhancement of ZnO nanorods prepared on glass substrates. Appl. Surf. Sci. 2018, 439, 285-297. [CrossRef]

17. Ohtomo, A.; Kawasaki, M.; Koida, T.; Masubuchi, K.; Koinuma, H. $\mathrm{Mg}_{x} \mathrm{Zn}_{1-x} \mathrm{O}$ as II-VI widegap semiconductor alloy. Appl. Phys. Lett. 1998, 72, 2466. [CrossRef]

18. Xie, A.; Yang, D.; Li, X.; Zeng, H. Lattice restraint induced ultra-large bandgap widening of ZnO nanoparticles. J. Mater. Chem. C 2019, 7, 8969-8974. [CrossRef]

19. Kasi, G.; Seo, J. Influence of Mg doping on the structural, morphological, optical, thermal, and visible-light responsive antibacterial properties of $\mathrm{ZnO}$ nanoparticles synthesized via co-precipitation. Mater. Sci. Eng. C 2019, 98, 717-725. [CrossRef]

20. Priscilla, S.J.; Daniel, R.; Dhakshayani, Y.; Caroline, S.C.; Sivaji, K. Effect of magnesium dopant on the structural, morphological and electrical properties of ZnO nanoparticles by sol-gel method. Mater. Today Proc. 2021, 36, 793-796. [CrossRef]

21. Hurma, T. Effect of boron doping concentration on structural optical electrical properties of nanostructured ZnO films. J. Mol. Struct. 2019, 1189, 1-7. [CrossRef]

22. Pon, V.D.; Wilson, K.S.J.; Hariprasad, K.; Ganesh, V.; Ali, H.E.; Algarni, H.; Yahia, I.S. Enhancement of optoelectronic properties of $\mathrm{ZnO}$ thin films by Al doping for photodetector applications. Superlattices Microstruct. 2021, 151, 106790.

23. Fay, S.; Feitknecht, L.; Schluchter, R.; Kroll, U.; Sauvain, E.V.; Shah, A. Rough ZnO layers by LP-CVD process and their effect in improving performances of amorphous and microcrystalline silicon solar cells. Sol. Energy Mater. Sol. Cells 2006, 90, $2960-2967$. [CrossRef]

24. Fay, S.; Steinhauser, J.; Nicolay, S.; Ballif, C. Polycrystalline ZnO: B grown by LPCVD as TCO for thin film silicon solar cells. Thin Solid Films 2010, 518, 2961-2966. [CrossRef]

25. Bindu, P.; Thomas, S. Estimation of lattice strain in ZnO nanoparticles: X-ray peak profile analysis. J. Theor. Appl. Phys. 2014, 8, 123-134. [CrossRef]

26. Mimouni, R.; Kamoun, O.; Yumak, A.; Mhamdi, A.; Boubaker, K.; Petkova, P.; Amlouk, M. Effect of Mn content on structural, optical, opto-thermal and electrical properties of ZnO: Mn sprayed thin films compounds. J. Alloys Compd. 2015, 645, 100-111. [CrossRef]

27. Basnet, P.; Chatterjee, S. Structure-directing property and growth mechanism induced by capping agents in nanostructured ZnO during hydrothermal sysnthesis-A systematic review. Nano-Struct. Nano-Objects 2020, 22, 100426. [CrossRef] 
28. Mohar, R.S.; Sugihartono, I.; Fauzia, V.; Umar, A.A. Dependence of optical properties of Mg-doped ZnO nanorods on Al dopant. Surf. Interfaces 2020, 19, 100518. [CrossRef]

29. San, H.S.; Li, B.; Feng, B.X.; He, Y.Y.; Chen, C. Effect on optical band-gap of transparent and conductive CdIn ${ }_{2} \mathrm{O}_{4}$ thin film due to defects-induced Burstein-moss and band-gap narrowing characteristics. Acta Phys. Sin. 2005, 54, 842-847. 